\begin{tabular}{|c|c|}
\hline \multirow{3}{*}{ 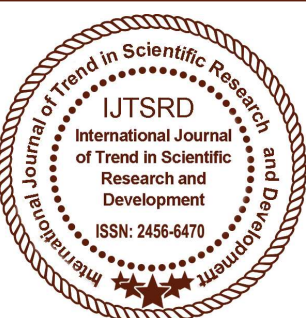 } & $\begin{array}{l}\text { International Journal of Trend in Scientific } \\
\text { Research and Development (IJTSRD) }\end{array}$ \\
\hline & International Open Access Journal \\
\hline & ISSN No: 2456 - 6470 | www.ijtsrd.com | Volume - 2 | Issue -3 \\
\hline
\end{tabular}

\title{
Symbol development to present Friction stir Butt weld experiment
}

\author{
Kaushal Bhavsar \\ Research Scholar, KSV University, Gandhinagar, \\ Gujarat, India
}

\author{
Dr. G. D. Acharya \\ Principal, Atmiya institute of Science and \\ Technology, Rajkot, Gujarat, India
}

\begin{abstract}
Friction stir welding is the process which have been famous from last 2 decades. The experiments carried are presented in bulk and no significant method is present to make the researcher understand what exactly the experiment was. For understanding the experiment a researcher must have to go through the article thoroughly and then observe and understand various data of experiment like the tooling, plate mounting as well other welding criteria. So the presentation of information is not in proper significant manner. Here an attempt have been made to make the learner, researcher as well the experts to make them understand symbolic presentation of experiments mentioning all data related to it. One should have to go through a small exercise to understand it for 1 time then easily one can adopt understanding about the same.
\end{abstract}

\section{Introduction}

The FSW concept was developed from ancient heat generation technique called "fire churning". Fire churning is used to develop divine agni (fire) to do yajna. In this process one wooden block is considered as spindle and the other is behaving as heat carrier or support. The spindle is revolved C.W. as well C.C.W. on the surface of the wooden block. Repetition of same have given heat as well fire at the mating surface of spindle and base wood. Here during the FSW process heat generation is done by same method. In FSW our tool is rotating in single direction to produce heat. Once heat is generated the material gets plasticized then feed is applied so the process diffuses material within and develop weld joint of metals. When the tool revolves as well gets plunged in metal heat is generated. Sometimes due to friction and heat the aluminum gets evaporated. The gaseous state which is coming out during FSW is aluminum oxide.

The whole symbolic presentation is depends on parameters used to conduct an experiments as well to present the row material, tool profile as well tool feature and shoulder feature, etc..

So primary task for any symbolic presentation is to collect the variables involved in the study. After that one should show the process visual in image as front view (Elevation) and top view (Plan) of the process. So the configured image symbol will be representing all the data which is important to understand during and after weld performance.

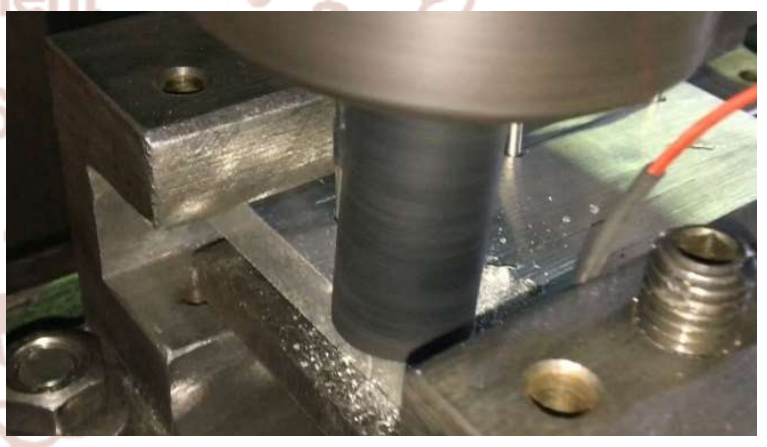

Figure 1: friction stir butt weld of $12 \mathrm{~mm}$ thick AA 7050plate

2. Variable collection and review:

PRIMARY VARIABLE PARAMETERS:

FSW process considers following parameters as primary parameters.

1) Weld plate material Type (Ferrous metals /Nonferrous metals

2) Material thickness 
3) Tool Material Type (Row material, Surface D3 conical with thread hardened, Etc...)

4) Spindle Speed (Tool rotational speed)

5) Spindle rotation direction (C.W. //C.C.W. - from direction of observer)

E E1 cylindrical tool

6) Feed (carriage feed)

F $\quad$ F1 frustum with flats ( Tria, Sq,

7) Feed direction ( + or - )

8) No of pass (for weld process) (+++, +-+,-+-, Etc......)

E2 cylindrical with groove

E3 cylindrical with thread

Pentagonal,Hexagonal,polygonal)

F2 frustum with flats + grooves

F3 frustum with flats + thread

9) Tool type (refer next slide)

10) Tool Plunge time

11) Depth of plunge for tool

12) Plunge load from tool

13) Tool tilt angle

14) Dwell time For stir action

15) Pre heating time (Raw material)

16) Pre heating temperature (Raw material)

Special Purpose tool:

17) Post heating time (Weld plate)

G G1 Bobbin cylindrical

G2 Bobbin cylindrical with grooves

18) Post heating temperature (Weld plate)

G3

Bobbin cylindrical with thread

G4 Bobbin conical

G5 Bobbin conical with grooves

19) 1 -Side ( 1 face / 1 direction) weld or 2 -side ( 2 face / 2 direction) weld.

G6 Bobbin conical with thread

H1 ${ }^{\prime}$ Helical gear processing tool

ISciel1 fifi Micro Channel Development tool

SHOULDER FEATURE:

Tool Shoulder Feature types:

SECONDARY VARIABLE PARAMETERS:

Tool Tip feature types available which should be considered while carrying experiments.

A A1 conical tool

A2 conical with groove

A3 conical with thread

B B1 cylindrical tool

B2 cylindrical with groove

B3 cylindrical with thread

C C1 frustum with flats (Tria, Sq, Pentagonal, Hexagonal, polygonal)

C2 frustum with flats + grooves

C3 frustum with flats + thread

D D1 conical tool

D2 conical with groove
SF1 Flat shoulder

SF2 Convex

SF3 Concave

SF4 Conical shoulder

SF5 Specific Curve (Bezier, Splines, etc)

\section{PROFILES ON SHOULDER FACE:}

PSF1 Hole (Through /Blind -small/large)

PSF2 Indentations

PSF3 Volutes

PSF4 Grooves, slots, channels

PSF5 Rings

The parameters presented here are required to present the experiment. The international journal and their authors are facing complexity in presenting the process parameters. Symbolic terms and meaning of each parameter involved with symbol. 
International Journal of Trend in Scientific Research and Development (IJTSRD) ISSN: 2456-6470

Weld type table:

\begin{tabular}{|l|l|l|}
\hline \multicolumn{1}{|c|}{$\begin{array}{c}\text { Sr. } \\
\text { no. }\end{array}$} & \multicolumn{1}{|c|}{$\begin{array}{l}\text { Neld } \\
\text { type sign }\end{array}$} & \\
\hline 1 & BFSW & Butt friction stir Weld \\
\hline 2 & LFSW & Lap friction stir Weld \\
\hline 3 & LSFSW & L-section friction stir weld \\
\hline 4 & CSFSW & C-section friction stir weld \\
\hline 5 & BSFSW & Box -section friction stir weld \\
\hline 6 & CHSFSW & $\begin{array}{l}\text { Channel section friction stir } \\
\text { weld }\end{array}$ \\
\hline 7 & BTFSW & Bobbin tool Friction stir weld \\
\hline 8 & BFSSW & Butt friction stir spot welding \\
\hline 9 & LFSSW & Lap friction stir spot Weld \\
\hline 10 & LSFSW & L-section friction stir spot weld \\
\hline 11 & CSFSW & C-section friction stir spot weld \\
\hline 12 & BSFSW & $\begin{array}{l}\text { Box -section friction stir spot } \\
\text { weld }\end{array}$ \\
\hline 13 & CHSFSW & $\begin{array}{l}\text { Channel section friction stir spot } \\
\text { weld }\end{array}$ \\
\hline
\end{tabular}

\begin{tabular}{|l|l|l|}
\hline $\begin{array}{c}\text { Sr. } \\
\text { no. }\end{array}$ & $\begin{array}{c}\text { TTY } \\
\text { (tool ti } \\
\text { Type) }\end{array}$ & \\
\hline 1 & CY & Cylindrical tip tool \\
\hline 2 & CYT & Cylindrical threaded tool \\
\hline 3 & CYS & Cylindrical slotted tool \\
\hline 4 & CYG & Cylindrical grooved, volute tool \\
\hline 5 & CO & Conical tip tool \\
\hline 6 & COT & Conical threaded tool \\
\hline 7 & COS & Conical slotted tool \\
\hline 8 & COG & Conical grooved, volute tool \\
\hline 9 & TR & Triangle tip tool \\
\hline 10 & TRT & Triangle threaded tool \\
\hline 11 & TRS & Triangle slotted tool \\
\hline 12 & TRG & Triangle grooved, volute tool \\
\hline 13 & SQ & Square tip tool \\
\hline 14 & SQT & Square tip threaded tool \\
\hline 15 & SQS & Square tip slotted tool \\
\hline 16 & SQG & Square tip grooved tool \\
\hline 17 & PE & Pentagonal tip tool \\
\hline 18 & PET & Pentagonal tip threaded tool \\
\hline 19 & PES & Pentagonal tool Slotted tool \\
\hline 20 & PEG & Pentagonal tool Grooved tool \\
\hline 21 & HX & Hexagonal tip tool \\
\hline 22 & HXT & Hexagonal tip threaded tool \\
\hline 23 & HXS & Hexagonal tip slotted tool \\
\hline 24 & HXG & Hexagonal tip grooved tool \\
\hline 25 & PO & Polygonal tip tool \\
\hline 26 & POT & Polygonal tip tool with thread \\
\hline 27 & POS & Polygonal tip tool with slot \\
\hline 28 & POG & Polygonal tip tool with groove \\
\hline & & \\
\hline 19 & & \\
\hline 19 & & \\
\hline 19 & &
\end{tabular}

\section{Symbolic presentation of friction stir Butt weld:}

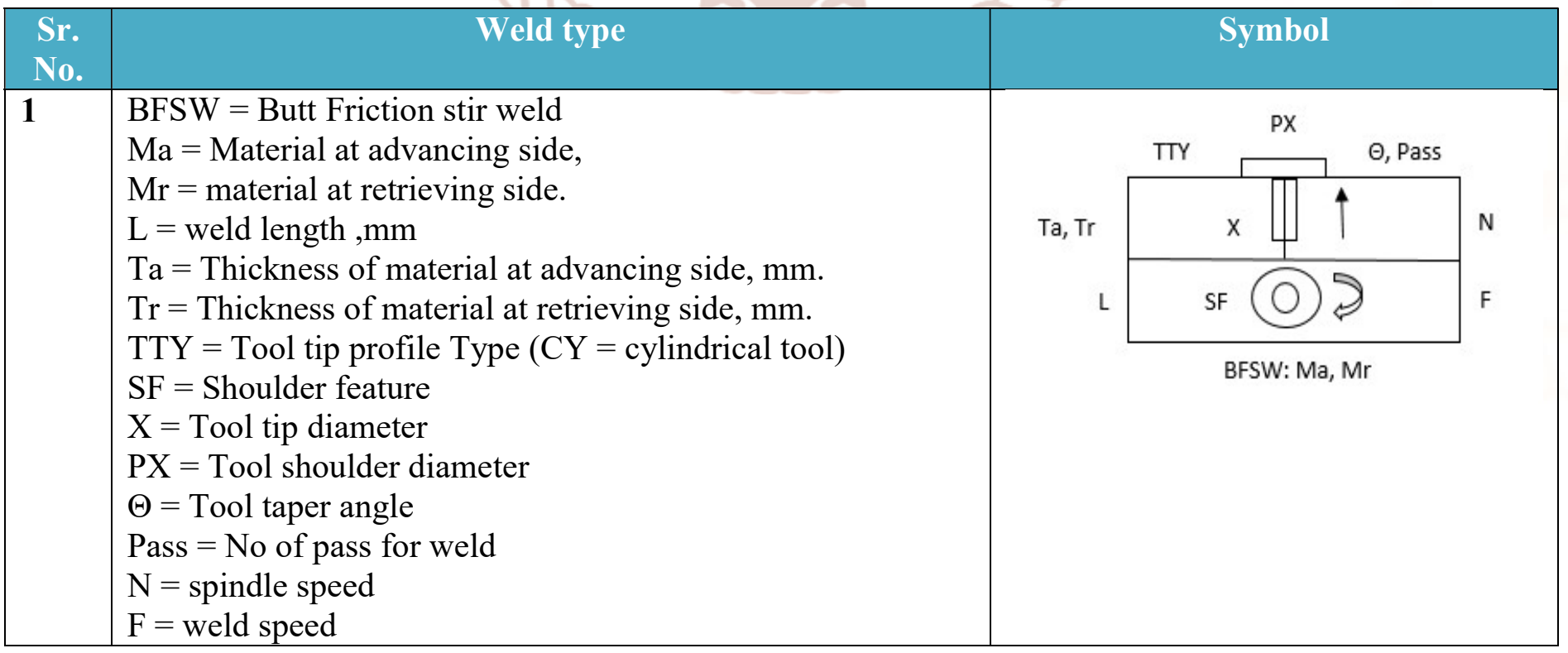


International Journal of Trend in Scientific Research and Development (IJTSRD) ISSN: 2456-6470

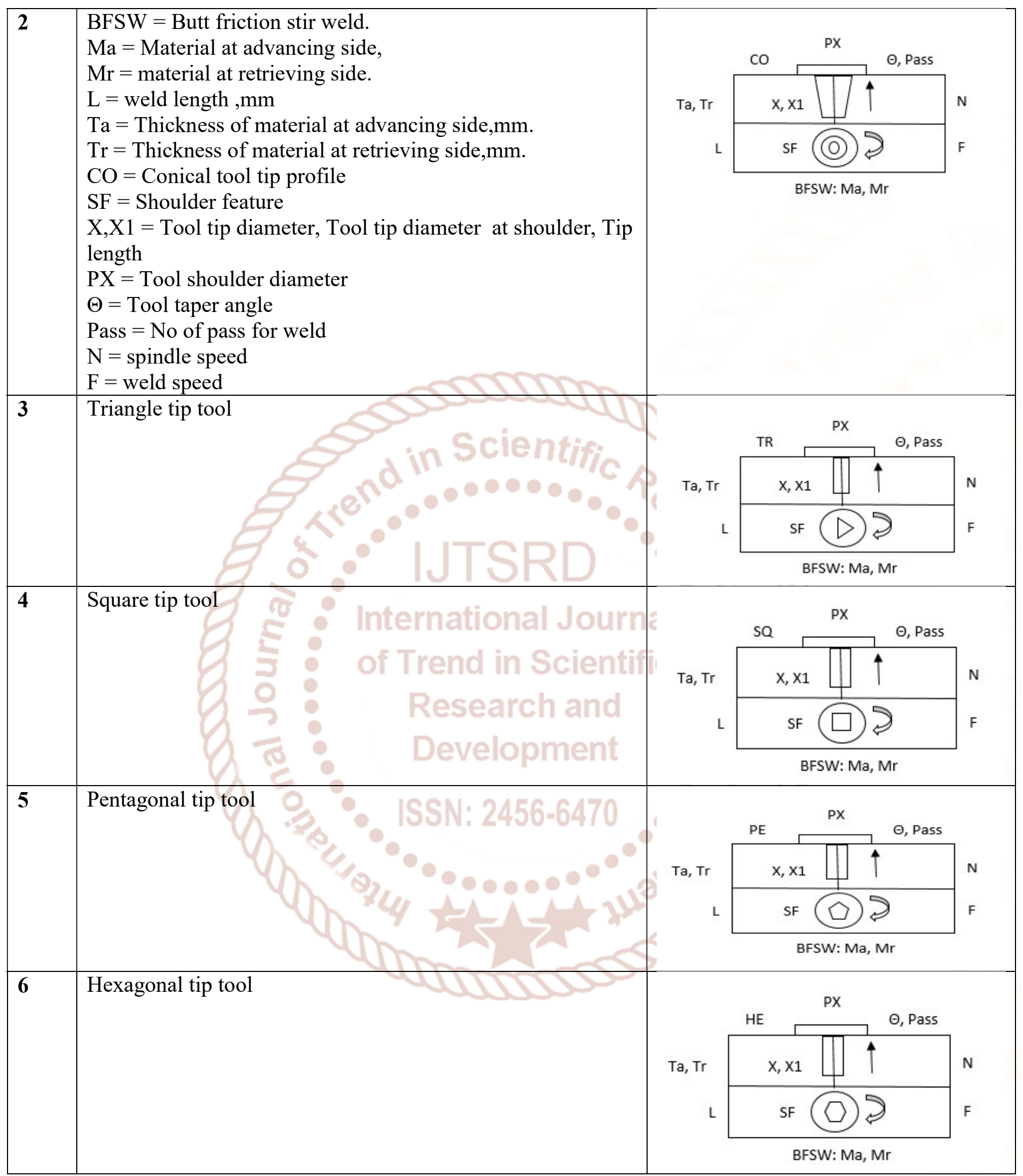

\section{Conclusion:}

Here if the researcher have experiment material for friction stir welding, AA7050-T7451 rolled plate at advancing as well retrieving side, the weld designated is butt friction stir weld having raw material plate size of about $100 \mathrm{~mm} \times 50 \mathrm{~mm} \times 12 \mathrm{~mm}$ and required Length of weld about $100 \mathrm{~mm}$, the plate thickness at advancing as well retrieving side are $12 \mathrm{~mm}$ each, The tool tip profile selected is cylindrical having tip 
diameter $6 \mathrm{~mm}$ at free end as well $6 \mathrm{~mm}$ at shoulder end with tip length of $10 \mathrm{~mm}$. Shoulder face is without feature, tool tilt angle of $2^{\circ}$, weld pass required is 1 . Spindle speed $=2000$ RPM, feed or weld speed is $120 \mathrm{~mm} / \mathrm{minute}$ and the tool rotation direction is C.W. with longitudinal movement then the symbol can be placed like below.

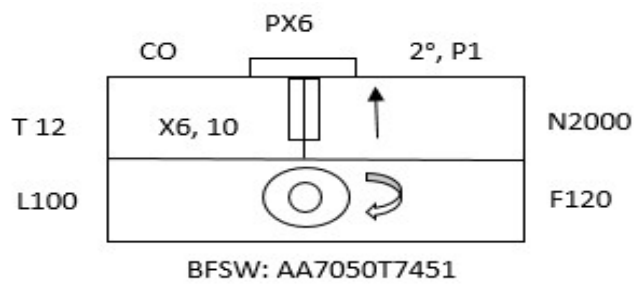

If with same processing configuration material at advancing side taken is $\mathrm{CU}$-Copper and at retrieving side AA-Aluminum alloy then the presentation will vary like Fig.. And if at advancing side AA and retrieving side AA then can be represented like fig.
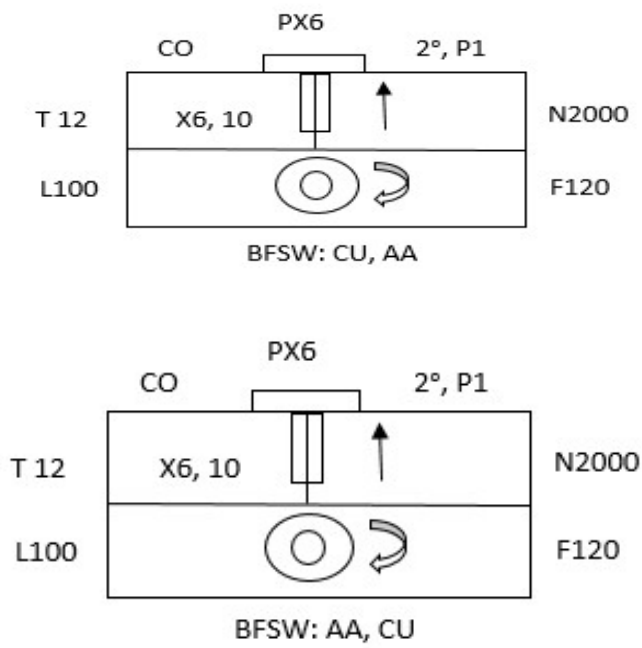

\section{References:}

1) J.Yan A.P.Reynold 'Effects of Initial Basemetal Temper on Mechanical Properties in Aa7050 Friction Stir Welds', Science and technology of welding and joining, 14 (2009), 282-87.

2) P.Upadhyay; A.P.Reynolds 'Effects of Thermal Boundary Conditionsin Friction Stirwelded Aa7050 T7 Sheets', Material science and engineering (2010), 1637-543.

3) Almazrouee AI Al-Fadhalah KJ, Aloraier AS, 'Microstructure and Mechanical Properties of Multi-Pass Friction Stir Processed Aluminum Alloy 6063', Materials \& Design, 53 (2014), 55060 .
4) De A Arora A, DebRoy T, 'Toward Optimum Friction Stir Welding Tool Shoulder Diameter.', Scripta Materialia, 64 (2011), 9-12.

5) Nandan R Arora A, Reynolds AP, DebRoy T, 'Torque, Power Requirement and Stir Zone Geometry in Friction Stir Welding through Modeling and Experiments', Scripta Materialia, 60 (2009), 13-16.

6) Zhang Z Arora A, De A, DebRoy T, 'Strains and Strain Rates During Friction Stir Welding', Scripta Materialia, 61 (2009), 863-66.

7) Serajzadeh $\mathrm{S}$ Azimzadegan $\mathrm{T}$, 'An Investigation into Microstructures and Mechanical Properties of Aa7075-T6 During Friction Stir Welding at Relatively High Rotational Speeds.', Journal of materials engineering and performance, 19 (2010), 1256-63.

8) Pillai B Bhatt KD, 'Simulation of Peak Temperature \& Flow Stresses During Friction Stir Welding of Aa7050-T7451 Aluminum Alloy Using Hyper Works. ', International Journal of Emerging Technology and Advanced Engineering, may 2012 (2012), 2250-459.

9) Michaleris P Bhide SR, Posada M, DeLoach J, 'Comparison of Buckling Distortion Propensity for Saw, Gmaw, and Fsw. ', Welding journal., 85 (2006), 189-95.

10) Tang W Brown R, Reynolds AP, 'Multi-Pass Friction Stir Welding in Alloy 7050-T7451: Effects on Weld Response Variables and on Weld Properties', Materials Science and Engineering: A, 513 (2009), 115-21.

11) Forcellese A Cabibbo M, El Mehtedi M, Simoncini M, 'Double Side Friction Stir Welding of Aa6082 Sheets: Microstructure and Nanoindentation Characterization', Materials Science and Engineering, 590 (2014), 209-17.

12) İpekoğlu G. Çam G, 'Recent Developments in Joining of Aluminum Alloys.', The International Journal of Advanced Manufacturing Technology, 91 (2017), 1851-66.

13) Moore MA Canaday CT, Tang W, Reynolds AP, 'Through Thickness Property Variations in a Thick Plate Aa7050 Friction Stir Welded Joint', Materials Science and Engineering: A, 62 (2013), 334-43.

14) Palazzo GS Carlone P, 'Acterization of Tig and Fsw Weldings in Cast Ze41a Magnesium Alloy. ', 
Journal of Materials Processing Technology, 215 (2015), 87-94.

15) V.Richter; E.Suzano; M.Beltrao; A.Roots; J.F.dos Santos; P.M.S.T. de castro, 'Influence of the Fsw Clamping Force on the Final Distortion and Residual Stress Field', Material science and engineering (2012), 81-88.

16) Qi X Chao YJ, Tang W, 'Heat Transfer in Friction Stir Welding-Experimental and Numerical Studies. ', Journal of manufacturing science and engineering., 125 (2003), 138-45.

17) Kovacevic R Chen CM, 'Finite Element Modeling of Friction Stir Welding-Thermal and Thermomechanical Analysis.', Journal of Machine Tools and Manufacture, 43 (2003), 1319-26.

18) Dongun kim; Harsha Badrinarayan;Ji Hoon Kim ;Cong min kim; Kazutaka Okamoto; R.H. Wagoner; Kwansoo Chung, 'Numerical Simulation of Friction Stir Butt Welsing Process Aa5083-H18 Sheets', Europian journal of mechanics 29 (2010), 204-15.

19) Shercliff HR Colegrove PA, '3-Dimensional Cfd Modelling of Flow Round a Threaded Friction Stir Welding Tool Profile.', Journal of materials processing technology, 169 (2005), 320-27.

20) Gibson BT Cox CD, DeLapp DR, Strauss AM, Cook GE, 'A Method for Double-Sided Friction Stir Spot Welding. ', Journal of Manufacturing Processes, 16 (2014), 241-47.

A. Deschamps D. Dumont, Y. Brechet, 'On the Relationship between Microstructure, Strength and Toughness in Aa7050aluminium Alloy', Materials Science and Engineering: A, 356 (2003), 326-36.

21) Giardini C D’Urso G, 'Thermo-Mechanical Characterization of Friction Stir Spot Welded Aa7050 Sheets by Means of Experimental and Fem Analyses.', Materials, 9 (2016), 689.

22) Bolmsjö G De Backer J, Christiansson AK., 'Temperature Control of Robotic Friction Stir Welding Using the Thermoelectric Effect.', The International Journal of Advanced Manufacturing Technology, 70 (2014), 375-83.

23) De A DebRoy T, Bhadeshia HK, Manvatkar VD, Arora 'Tool Durability Maps for Friction Stir Welding of an Aluminium Alloy.', The Royal Society, 468 (2012), 3552-70.
24) Ma N Deng D, Murakawa H, 'Finite Element Analysis of Welding Distortion in a Large ThinPlate Panel Structure.', Transactions of JWRI, 40 (2011), 89-100.

25)* Dirk Schwingela, Hans-Wolfgang Seeligera, Claude Vecchionaccib,Detlef Alwesc, Jürgen Dittrichc 'Aluminium Foam Sandwich Structures for Space Applications', Acta Astronautica, 61 (2007), 326-30.

26) Jin LZ Ericsson M, Sandström R, 'Fatigue Properties of Friction Stir Overlap Welds.', International journal of fatigue, 29 (2007), 57-68.

27) M. seidi; B manafi; MK Besharati Givi; G Faraji, 'Mathematical Modelling and Optimisation of Friction Stir Welding Process Parameters in Aa7075 and Aa5083 Aluminium Alloy Joint', Journal of Engineering manufacture (2015), 1-11.

28) Fsw-Vi. ed. by The welding institute UK, Articles by Twi (2013).

29) Lammlein DH Gibson BT, Prater TJ, Longhurst WR, Cox CD, Ballun MC, Dharmaraj KJ, Cook GE, Strauss AM., 'Friction Stir Welding: Process, Automation, and Control.', Journal of Manufacturing Processes, 16 (2014), 56-73.

30) Chunlin DO Guohong XW, 'Microstructures and Mechanical Properties of Friction Stir Welded Joints of Aluminium Alloy Thick Plate with Different Welding States.', Acta Metall 45 (2009), 490-96.

31) C HAMILTON, 'A Thermal Model of Friction Stir Welding in Aluminum Alloys.', International journal of machine tools and manufacture, 48 (2008), 1120-30.

32) MacKenzie D Hamilton R, Li H., 'Multi-Physics Simulation of Friction Stir Welding Process.', Engineering Computations, 27 (2010), 967-85.

33) Wan FR Han WT, Li G, Dong CL, Tong JH, 'Effect of Trailing Heat Sink on Residual Stresses and Welding Distortion in Friction Stir Welding Al Sheets', Science and Technology of Welding and Joining., 16 (2011), 453-58.

34) Ling $\mathrm{Z}$ He J, Li H, 'Effect of Tool Rotational Speed on Residual Stress, Microstructure, and Tensile Properties of Friction Stir Welded 6061T6 Aluminum Alloy Thick Plate.', The International Journal of Advanced Manufacturing Technology, 84 (2016), 1953-61. 
International Journal of Trend in Scientific Research and Development (IJTSRD) ISSN: 2456-6470

35) Hino $\mathrm{H}$ Hori $\mathrm{H}$, 'Application of Friction Stir Welding to the Car Body', Welding international, 17 (2003), 287-92.

36) Scheuring J Huang X, Reynolds AP, Fsw of High Strength 7xxx Aluminum Using Four Process Variants, Infriction Stir Welding and Processing Viii (2015).

37) Iss Training Manual ,Chapter-9. ed. by NASA2008 (2008).

38) Jamaludin MF Janasekaran S, Yusof F, Shukor $\mathrm{MH}$, Ariga $\mathrm{T}$, 'Influence of Ba4047 Filler Addition through Mamdani Fuzzy Logic Optimization for Double-Sided T-Joint Welding of Aluminum Alloys Using Low-Power Fiber Laser.', The International Journal of Advanced Manufacturing Technology, 93 (2017), 2133-43.

39) Zhang J Ji P, Zheng L, Xiao Y, Dou S, Cui X, Lian Y, 'Comparison of Residual Stress Determination Using Different Crystal Planes by Short-Wavelength X-Ray Diffraction in a Friction-Stir-Welded Aluminum Alloy Plate', Journal of Materials Science, 52 (2017), 1283447.

40) DRAGNEVSKI K JUN TS, KORSUNSKY AM., 'Microstructure, Residual Strain, and Eigenstrain Analysis of Dissimilar Friction Stir Welds', Materials \& Design., 31 (2010), 121-25.

41) Tolephih MH Jweeg MJ, Abdul-Sattar M, 'Theoretical and Experimental Investigation of Transient Temperature Distribution in Friction Stir Welding of Aa 7020-T53', Journal of engineering, 18 (2012), 693-709.

42) Karidi S Katre S, Rao BD, Ramulu PJ, Narayanan RG, 'Springback and Formability Studies on Friction Stir Welded Sheets.', Advances in Material Forming and Joining (2015), 141-65.

43) Esme U Kulekci MK, Buldum B, 'Critical Analysis of Friction Stir-Based Manufacturing Processes', The International Journal of Advanced Manufacturing Technology, 85 (2016), 1687-712.

44) Yadav D Kumar A, Perugu CS, Kailas SV., 'Influence of Particulate Reinforcement on Microstructure Evolution and Tensile Properties of in-Situ Polymer Derived Mmc by Friction Stir Processing', Materials \& Design, 113 (2017), 99108.

45) Varghese S Kumar AR, Sivapragash M, 'A Comparative Study of the Mechanical Properties of Single and Double Sided Friction Stir Welded Aluminium Joints', Procedia engineering, 38 (2012), 3951-61.

46) Kailas SV Kumar K, Srivatsan TS., 'Influence of Tool Geometry in Friction Stir Welding', Materials and Manufacturing Processes, 23 (2008), 188-94.

47) Kailas SV Kumar K, Srivatsan TS. , 'The Role of Tool Design in Influencing the Mechanism for the Formation of Friction Stir Welds in Aluminum Alloy 7020', Materials and Manufacturing Processes, 26 (2011), 915-21.

48) Diamantakos ID Lampeas GN, 'Effects of Nonconventional Tools on the ThermoMechanical Response of Friction Stir Welded Materials', Journal of manufacturing science and engineering., 137 (2015), 510-20.

49) Dubourg L Larose S, Perron C, Jahazi M, Wanjara $\mathrm{P}$, 'Limitation of Distortion in Friction Stir Welded (Fsw) Panels Using Needle Peening', InMaterials Science Forum, 638 (2010), 1203-08.

50) Webb BW Liechty BC, 'Modeling the Frictional Boundary Condition in Friction Stir Welding', International Journal of Machine Tools and Manufacture, 48 (2008), 1474-85.

51) Reynolds AP Lockwood WD, 'Simulation of the Global Response of a Friction Stir Weld Using Local Constitutive Behavior', Materials Science and Engineering: A, 339 (2003), 35-42.

52) Strauss AM Longhurst WR, Cook GE, Cox CD, Hendricks CE, Gibson BT, Dawant YS, 'Investigation of Force-Controlled Friction Stir Welding for Manufacturing and Automation. ', Journal of Engineering Manufacture, 224 (2010), 937-49.

53) Strauss AM Longhurst WR, Cook GE, Fleming PA, 'Torque Control of Friction Stir Welding for Manufacturing and Automation.', The International Journal of Advanced Manufacturing Technology, 51 (2010), 905-13.

54) KOMARASAMY M, 'Characterization of 3" through-Thickness Friction Stir Welded 7050T7451 Al Alloy. ', Materials Science and Engineering, 716 (2018 Jan 9.), 55-62.

55) H.M.Arbogh . M.Bellet, 'Experimental Validation of Finite Element Codes for Welding Dformations', Journal of material processing technology (2010). 
56) KOOHBOR B MALLON S, KIDANE A, REYNOLDS AP, 'On the Effect of Microstructure on the Torsional Response of Aa7050-T7651 at Elevated Strain Rates', Materials Science and Engineering: A, 639 (2015), 280-87.

57) Rice J Mandal S, Elmustafa AA, 'Experimental and Numerical Investigation of the Plunge Stage in Friction Stir Welding', Journal of materials processing technology, 203 (2008), 411-19.

58) Ke L Mao Y, Chen Y, Liu F, Xing L, 'Improving Local and Global Mechanical Properties of Friction Stir Welded Thick Aa7075-T6 Joints by Optimizing Pin-Tip Profile', The International Journal of Advanced Manufacturing Technology, 88 (2017), 1863-75.

59) Ke L Mao Y, Chen Y, Liu F, Xing L., 'Improving Local and Global Mechanical Properties of Friction Stir Welded Thick Aa7075-T6 Joints by Optimizing Pin-Tip Profile. ', The International Journal of Advanced Manufacturing Technology, 88 (1 FEB 2017), 1863-75.

60) Ke L Mao Y, Liu F, Liu Q, Huang C, Xing L, 'Effect of Tool Pin Eccentricity on Microstructure and Mechanical Properties in Friction Stir Welded 7075 Aluminum Alloy Thick Plate', Materials \& Design, 8 (2014), 175-83.

61) Marcello Cabibbo Michela Simoncini, Archimede Forcellese, 'Development of Double-Side Friction Stir Welding to Improve Post-Welding Formability of Joints in Aa6082 Aluminium Alloy', JOURNAL OF ENGINEERING MANUFACTURE, 230(5) (2015), 807-17.

62) De PS Mishra RS, Kumar N, Friction Stir Welding and Processing: Sciemce and Engineering (Springer, 2014).

63) Labeas GN. Moraitis GA, 'Investigation of Friction Stir Welding Process with Emphasis on Calculation of Heat Generated Due to Material Stirring', Science and Technology of Welding and Joining., 15 (2010), 177-84.

64) Dean Deng; Wei Liange; Hidekazu Murakava, 'Determination of Welding Deformation in Fillet Welded Joint by Means of Numerical Simulation and Comparison with Experimental Measurements', Journal of material processing technology (2007), 219-55.
65) McPherson NA, 'Plate Distortion-the Ongoing Problem in Shipbuilding', Journal of Ship Production, 23 (2007), 94-117.

66) DebRoy $T$ Nandan R, Bhadeshia HK, 'Recent Advances in Friction-Stir Welding-Process, Weldment Structure and Properties', Progress in Materials Science, 53 (2008), 980-1023.

67) Roy GG Nandan R, Debroy T, 'Numerical Simulation of Three-Dimensional Heat Transfer and Plastic Flow During Friction Stir Welding', Metallurgical and materials transactions 37 (2006), 1247-59.

68) Roy GG Nandan RG, Lienert TJ, Debroy T, 'Three-Dimensional Heat and Material Flow During Friction Stir Welding of Mild Steel', Acta materialia, 55 (2007), 883-95.

69) Hatamleh O., 'The Effects of Laser Peening and Shot Peening on Mechanical Properties in Friction Stir Welded 7075-T7351 Aluminum', Journal of Materials Engineering and Performance, 17 (2008), 688-94.

70) A.P. Reynolds P.Upadhyay, 'Effects of Thermal Boundary Conditions in Friction Stir Welded Aa7050-T7 Sheets', Materials Science and Engineering: A, 527 (2010), 1537-43.

71) Wu CS Padhy GK, Gao S, 'Friction Stir Based Welding and Processing Technologies-Processes, Parameters, Microstructures and Applications: A Review', Journal of Materials Science \& Technology (2017).

72) PATEL JB PATEL HP, BARAIYA KK., 'Simulation of Temperature, Viscosityand Flow Stress During Friction Stir Welding on Aa6063in T-Joint', INTERNATIONAL JOURNAL OF ENGINEERING SCIENCES \& RESEARCH TECHNOLOGY. 